\title{
21. PROBING THE TAG HYDROTHERMAL MOUND AND STOCKWORK: OXYGEN-ISOTOPIC PROFILES FROM DEEP OCEAN DRILLING ${ }^{1}$
}

\author{
Jeffrey C. Alt ${ }^{2}$ and Damon A.H. Teagle
}

\begin{abstract}
Oxygen isotope analyses carried out on quartz separates and whole rocks from the Trans-Atlantic Geotraverse (TAG) hydrothermal mound and the underlying stockwork zone document temperatures and processes within and beneath the mound. The mound is $25-40 \mathrm{~m}$ thick and consists of pyrite-rich, anhydrite-rich, and siliceous breccias, which nearly all contain quartz. The underlying pervasively quartz-veined stockwork is zoned, with quartz + paragonite + pyrite assemblages down to 101 mbsf, followed by paragonite + quartz + pyrite to $111 \mathrm{mbsf}$, and then chlorite + quartz + pyrite assemblage to the maximum depth penetrated, $125.7 \mathrm{mbsf}$.

Basement beneath the eastern and western margins of the mound ranges from fresh basalt $\left(\delta^{18} \mathrm{O}=5.9 \%\right)$, to basalt affected by low-temperature smectitic alteration $\left(\delta^{18} \mathrm{O}=6.4 \% o-6.8 \%\right.$ ) , and partly to totally chloritized basalts $\left(\delta^{18} \mathrm{O}=2.1 \% o-4.5 \%\right.$ ) . Whole-rocks from the deep chloritic stockwork have $\delta^{18} \mathrm{O}$ values of $2.1 \% c^{-5.7 \%}$, and chlorites have inferred values of $1 \% o^{-}$ $3 \%$. Chloritization of basalt at the margins of the mound and at depth proceeded via reaction of basalt with variable mixtures of seawater and hydrothermal fluids, at temperatures of $\sim 250^{\circ}-350^{\circ} \mathrm{C}$ and at integrated water/rock mass ratios of at least $30-300$.

Chloritization by early $\mathrm{Mg}$-bearing hydrothermal fluids was followed by reaction of the chloritized rocks with $\mathrm{Mg}$ depleted, alkali-enriched hydrothermal fluids having elevated $\mathrm{Na} / \mathrm{K}$ ratios to produce the paragonite + quartz + pyrite assemblage characteristic of the main TAG stockwork. Stockwork quartz has $\delta^{18} \mathrm{O}=7.9 \%{ }^{-11.7 \%}$, indicating temperatures of $260^{\circ}-$ $360^{\circ} \mathrm{C}$ in equilibrium with hydrothermal fluid $(1.7 \%$ ). The maximum temperatures calculated for quartz yield temperatures identical to those of the vent fluids $\left(360^{\circ}-365^{\circ} \mathrm{C}\right)$. Scatter to higher $\delta^{18} \mathrm{O}$ and lower calculated temperatures are the results of precipitation of quartz during cooling of hydrothermal fluids and mixing with seawater in the subsurface, plus local ${ }^{18} \mathrm{O}$-enrichments of fluids via interactions with wallrocks. Generally higher $\delta^{18} \mathrm{O}$ values of quartz from the mound compared to the stockwork $(12.3 \% \circ \pm 2.7 \%$ ov. $8.9 \%$ $\pm 0.9 \%$, respectively) reflect lower temperatures in the mound as the result of cooling of the mound by entrained seawater.
\end{abstract}

\section{INTRODUCTION}

The formation of new crust at mid-ocean ridges provides a heat source that drives hydrothermal circulation of seawater through the crust. This circulation significantly affects the heat budget for ocean crust (Stein and Stein, 1994) and subsurface reactions exert important influences on the isotopic and chemical compositions of seawater and oceanic crust (Edmond et al., 1979b). The surficial manifestations of these hydrothermal systems are the spectacular black smokers emitting $350^{\circ}-400^{\circ} \mathrm{C}$ hydrothermal fluids and the sulfide deposits that form at these hydrothermal vents. The Trans-Atlantic Geotraverse (TAG) hydrothermal mound, at $26^{\circ} \mathrm{N}$ on the Mid-Atlantic Ridge, is the largest massive sulfide deposit discovered to date on an unsedimented mid-ocean ridge (MOR), and is comparable in size to Cyprus-type massive sulfide deposits in ophiolites (Rona et al., 1993; Humphris et al., 1995).

In the fall of 1994, Leg 158 of the Ocean Drilling Program (ODP) drilled a series of holes into the TAG mound and the underlying stockwork feeder zone. The objectives were to determine the internal stratigraphy of the mound, to test models for the growth and evolution of massive sulfide deposits, and to investigate fluid flow, alteration, and the subsurface nature of an active hydrothermal system on an unsedimented MOR. Low-temperature $\left(<50^{\circ} \mathrm{C}\right)$ diffuse flow ac-

${ }^{1}$ Herzig, P.M., Humphris, S.E., Miller, D.J., and Zierenberg, R.A. (Eds.), 1998. Proc. ODP, Sci. Results, 158: College Station, TX (Ocean Drilling Program).

${ }^{2}$ Department of Geological Sciences, 2534 C.C. Little Building, The University of Michigan, Ann Arbor, MI 48109-1063, U.S.A. jalt@umich.edu counts for up to $90 \%$ of the total heat flux from MOR vent fields (Rona and Trivett, 1992; Schultz et al., 1992); consequently, the subsurface reactions converting black smoker fluids to diffuse flow may significantly affect the net mass and isotopic transport from MOR hydrothermal systems. These reactions include mixing of high-temperature hydrothermal fluids with seawater and precipitation of sulfides, U, and Si (Edmond et al., 1979a, 1995; Mills et al., 1996). Many of these reactions may occur within or adjacent to the subsurface stockwork zone (Janecky and Shanks, 1988), but the effects of fluid-rock interactions in upflow zones have not been directly observed at subsurface depths beyond a few meters (Embley et al., 1988; Alt, 1995). This paper presents the results of an oxygen isotopic study of samples from Leg 158 that addresses the above questions, particularly regarding the temperatures and compositions of fluids and their evolution in the shallow $(\sim 100 \mathrm{~m})$ subsurface.

\section{GEOLOGIC SETTING OF THE TAG MOUND}

The geologic setting of the TAG mound has been reviewed recently by Rona et al. (1993) and Humphris, Herzig, Miller, et al. (1996), and is briefly summarized here. The TAG hydrothermal field is located at $26^{\circ} \mathrm{N}$ on the Mid-Atlantic Ridge, and covers an area of 5 $\times 5 \mathrm{~km}$ near a salient at the base of the east wall of the median valley (Fig. 1). Low-temperature hydrothermal activity, with Mn oxide and nontronite deposits, occurs at $2400-3100 \mathrm{~m}$ on the east wall (Fig. 1). Inactive sulfide deposits, which are recrystallized and partly oxidized, occur in two zones on the lower east wall northeast of the active TAG mound (the MIR and ALVIN zones in Fig. 1). U/Th dating suggests that these relict deposits range from $5 \times 10^{3}$ to $14 \times 10^{3} \mathrm{yr}$ old (Lalou et al., 1995).

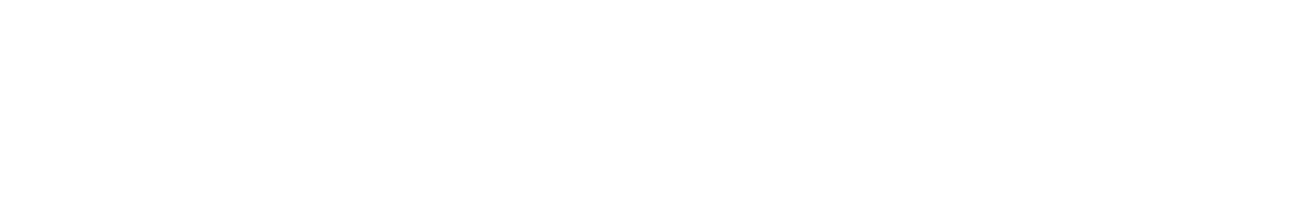


Figure 1. Bathymetry and features of the TAG hydrothermal field (from Humphris, Herzig, Miller, et al., 1996). Inset shows location of TAG on the Mid-Atlantic Ridge. The active TAG mound (solid circle) is located on 100,000 -yr-old crust east of the axis of spreading. Relict sulfide deposits (ALVIN and MIR) and low-temperature hydrothermal fields are located to the north and east of the active mound. temp $=$ temperature.

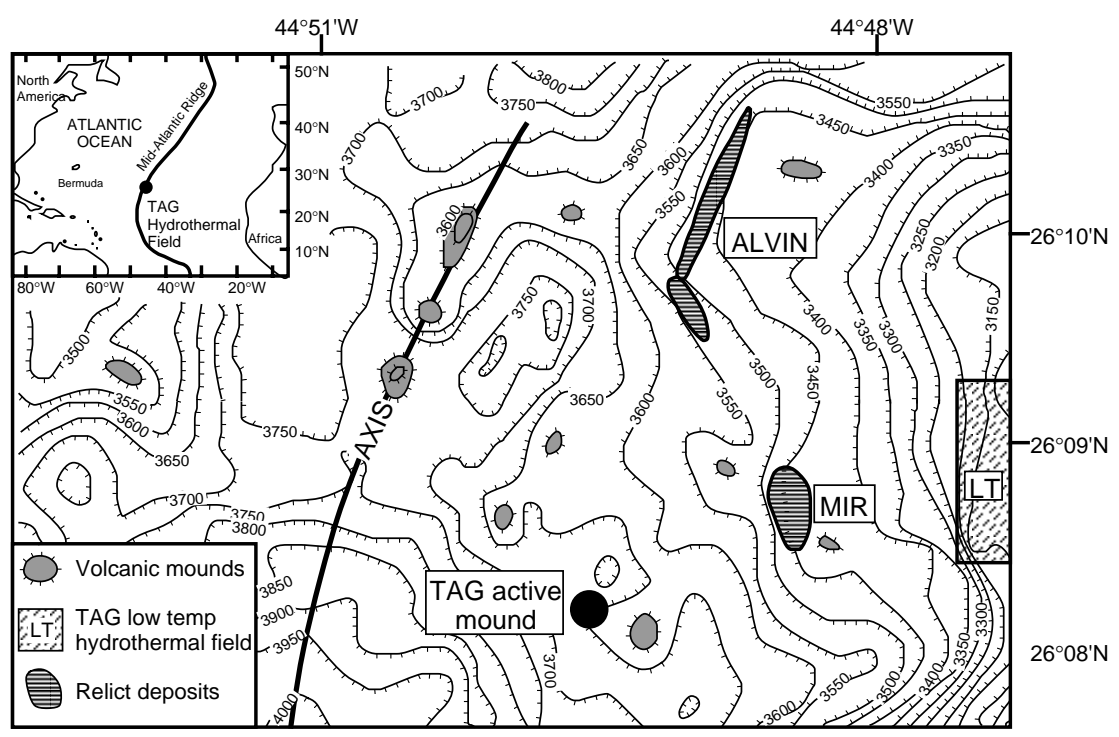

The active TAG mound is located at $26^{\circ} 08^{\prime} \mathrm{N}, 44^{\circ} 49^{\prime} \mathrm{W}$ at a water depth of about $3600 \mathrm{~m}$ (Fig. 1). It lies 1.5-2.0 km east of the spreading axis, on crust that is at least $100 \times 10^{3} \mathrm{yr}$ old. The mound is roughly circular, about $200 \mathrm{~m}$ in diameter and 30-50 m high (Fig. 2; Kleinrock et al., 1995). In plan the mound is asymmetric, with a cluster of chalcopyrite + anhydrite-rich black smoker chimneys discharging hydrothermal fluids at temperatures of up to $368^{\circ} \mathrm{C}$ located atop a 10 $15 \mathrm{~m}$ high, 20-30 m diameter cone to the northwest of the center of the mound (Fig. 2). The Black Smoker Complex is surrounded by an upper terrace at $\sim 3644 \mathrm{~m}$ and a lower terrace to the southeast at $\sim 3650$ $\mathrm{m}$. The Kremlin area on the lower terrace comprises a complex of small (1-2 m) sphalerite-rich white smokers. These emit $260^{\circ}-300^{\circ} \mathrm{C}$ fluids, which are interpreted to be derived from black smoker type fluids via a combination of cooling, mixing with seawater, and reactions within the mound (precipitation of pyrite, chalcopyrite and anhydrite, dissolution of sphalerite; Edmond et al., 1995; Tivey et al., 1995; Mills and Elderfield, 1995). Steep slopes on the west, north, and east sides of the upper terrace are the result of mass wasting, which has exposed material rich in silica (quartz and amorphous silica) \pm pyrite $\pm \mathrm{Fe}$ oxyhydroxides (Tivey et al., 1995).

Diffuse flow of low-temperature (up to $50^{\circ} \mathrm{C}$ ) fluids occurs through much of the surface of the mound and the surrounding sediment apron, which consists of mixtures of pelagic sediment and hydrothermal detritus and precipitates (Becker and Von Herzen, 1996; Mills et al., 1996). In other areas, particularly on the northwest side of the upper terrace, low heat flow suggests recharge of seawater into the mound (Becker and Von Herzen, 1996).

A near-bottom magnetic survey over the TAG mound indicates a magnetic low that lies directly beneath the deposit (Tivey et al., 1993). This has been interpreted as a cylindrical alteration pipe, possibly dipping to the south, that marks the shallow hydrothermal upflow zone (Tivey et al., 1993). The intersection of axis-parallel faults with transverse or oblique faults may influence the location of the TAG deposit (Karson and Rona, 1990; Kleinrock et al., 1995). Reactivation of such faults may help explain the proposed long duration of hydrothermal activity focused at the TAG deposit: U/Th dating of samples from the TAG mound suggest that hydrothermal activity has occurred there episodically over a period of at least 40,000-50,000 yr (Lalou et al., 1995). The documented mobility of $U$ within the mound (Mills et al., 1996), however, may affect these age estimates.

\section{LITHOLOGY AND STRATIGRAPHY OF THE TAG MOUND AND STOCKWORK FROM LEG 158 RESULTS}

Seventeen holes were drilled in five general areas of the TAG mound during Leg 158 (TAG-1 through TAG-5 in Fig. 3; Table 1). Shipboard scientists classified 20 different rock types in the TAG drill core (Humphris, Herzig, Miller, et al., 1996). Each piece of core, typically a few centimeters long, was classified individually, consequently the stratigraphy is complicated at a fine scale. At a larger scale, however, the mound can be divided into relatively few lithologic zones (Fig. 3). The uppermost 5-20 m of the mound consists mainly of pyrite breccias that contain clasts of pyrite or massive pyrite in a pyrite matrix. These breccias also contain local concentrations of chalcopyrite and sphalerite, plus common minor quartz and/ or anhydrite in the matrix. Near the Black Smoker Complex in the central and northern parts of the mound (TAG-1 and TAG-5 areas), the pyrite breccias are underlain by a 10 - to 15 -m-thick anhydrite-rich zone. Anhydrite-rich breccias are also present in Hole $957 \mathrm{H}$ to the east (TAG-2). The anhydrite zone consists mainly of pyrite-anhydrite breccias that contain clasts of pyrite \pm siliceous material (quartz + pyrite, silicified basalt fragments, clasts of other quartz-rich breccias) in a matrix containing greater than $10 \%$ anhydrite. Anhydrite veins are common locally in these rocks. The massive pyrite breccias and anhydrite-rich rocks are in turn underlain by pyrite-silica breccias, which consist of clasts of pyrite, quartz + pyrite, and/or siliceous material (as above), in a quartz-rich (>10\%) matrix. Anhydrite veins, up to $45 \mathrm{~cm}$ wide and exhibiting multiple stages of precipitation and dissolution, are common in the pyrite-silica breccias at TAG-1, and smaller (millimeter-centimeter sized) anhydrite veins are common in the pyrite-silica breccias at TAG-2 and TAG-5.

Variable proportions of silicified wallrock breccias occur with pyrite-silica breccias below 25-35 mbsf at TAG-1, TAG-4, and TAG5. Altered and silicified basalt clasts become much more abundant in the pyrite-silica breccias below this depth, which marks the top of the stockwork zone. The silicified wallrock breccias consist of pale gray to buff fragments of altered basalt that are veined and cemented by quartz and pyrite. Basalt clasts are totally replaced by quartz, paragonite, pyrite, a microcrystalline Ti-bearing phase, and traces of chlorite. The clasts are veined and cemented by $0.01-$ to $2-\mathrm{mm}$ veins of 


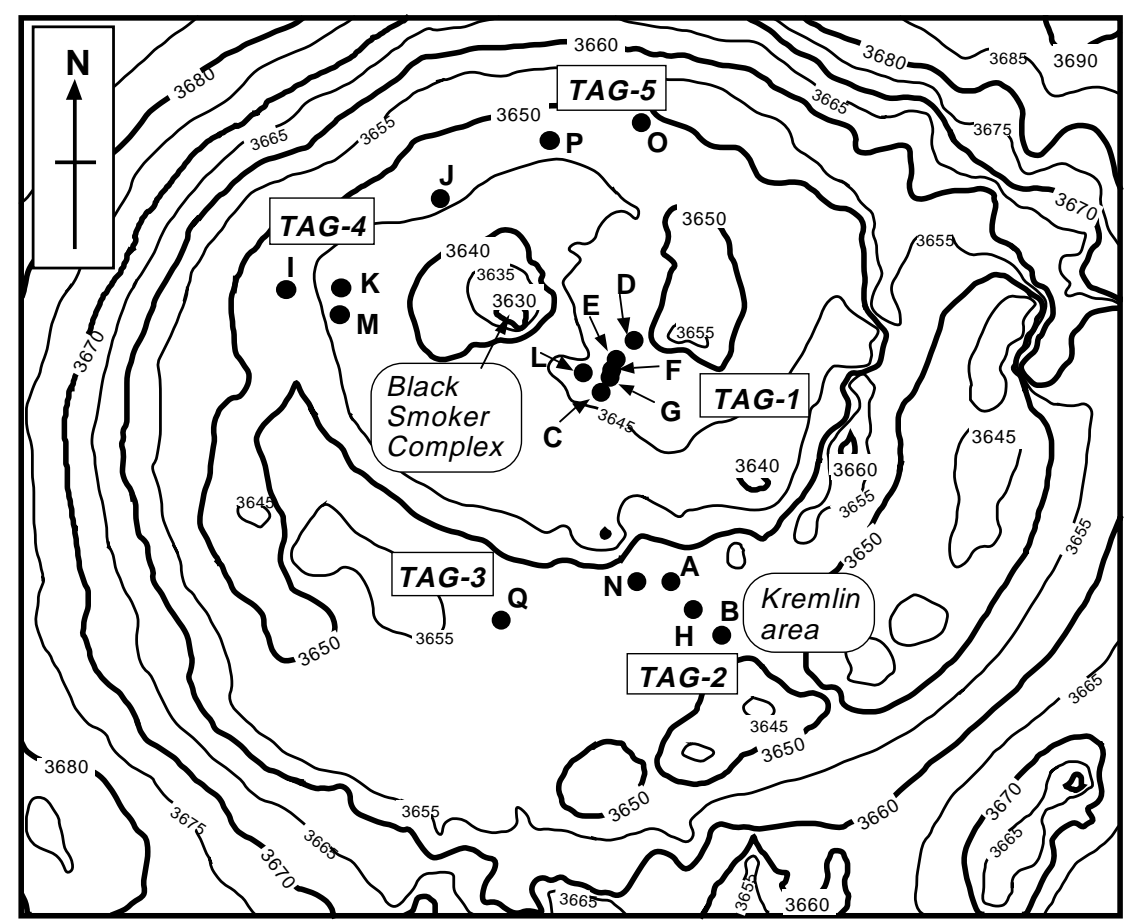

$\begin{array}{llllll}0 & 10 & 20 & 30 & 40 & 50 \text { meters }\end{array}$

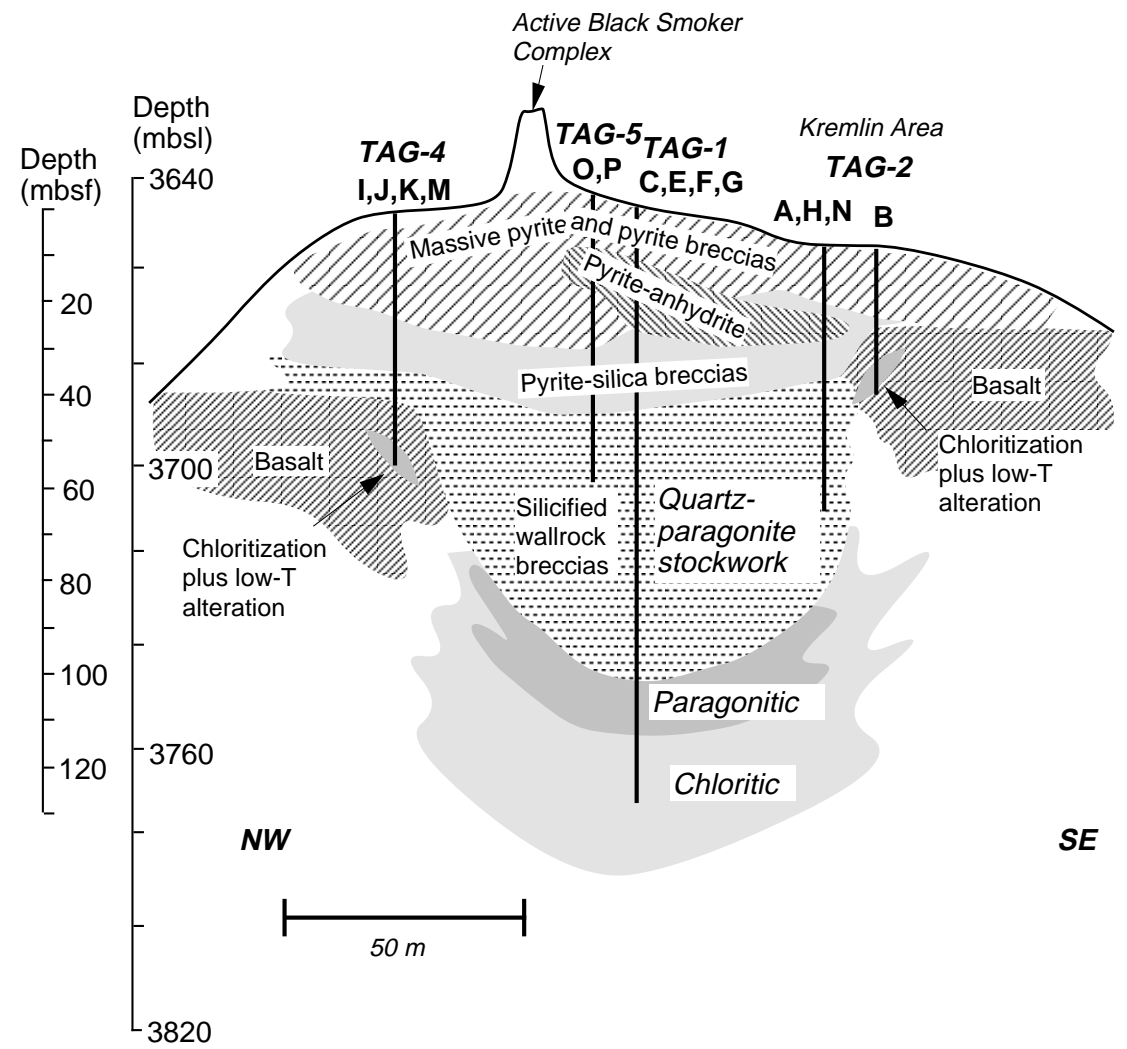

Figure 2. Detailed bathymetry of the TAG mound and locations of Leg 158 drill holes (solid circles). Drill holes are grouped into five areas (TAG-1 through TAG-5). See text for detailed descriptions. Contour interval $=5 \mathrm{~m}$.
Figure 3. Northwest-southeast cross section showing the generalized lithology and stratigraphy of the TAG mound and stockwork. The stratigraphy of TAG-5, which lies to the north of the Black Smoker Complex (see Fig. 2), is projected onto the cross section. See text for details. Depths in meters below sea level (mbsl) and meters below seafloor (mbsf), for TAG-1 and TAG-4; seafloor at TAG-2 is $10 \mathrm{~m}$ deeper than at TAG-1. 
Table 1. Leg 158 drilling and coring results.

\begin{tabular}{ccrrrr}
\hline Area & Hole & $\begin{array}{c}\text { Meters } \\
\text { cored }\end{array}$ & $\begin{array}{c}\text { Penetration } \\
(\mathrm{mbsf})\end{array}$ & $\begin{array}{r}\text { Recovery } \\
(\%)\end{array}$ & Comments \\
\hline TAG-1 & $957 \mathrm{C}$ & 49.2 & 49.2 & 44.1 & \\
& $957 \mathrm{D}$ & & & 0.0 & \\
& $957 \mathrm{E}$ & 94.2 & 125.7 & 4.3 & \\
& $957 \mathrm{~F}$ & 9.0 & 10.0 & 10.5 & \\
& $957 \mathrm{G}$ & 13.0 & 25.0 & 8.6 & \\
TAG-2 & $957 \mathrm{~L}$ & & & & \\
& $957 \mathrm{~A}$ & 15.0 & 15.0 & 1.7 & \\
& $957 \mathrm{~B}$ & 29.6 & 29.6 & 5.6 & \\
& $957 \mathrm{H}$ & 45.8 & 54.5 & 10.9 & \\
TAG-3 & $957 \mathrm{~N}$ & 42.2 & 42.2 & 1.0 & Single 42.2-m wash core. \\
TAG-4 & $957 \mathrm{Q}$ & 14.5 & 14.5 & 41.0 & Drill cuttings. \\
& $957 \mathrm{I}$ & 4.5 & 13.5 & 17.1 & \\
& $957 \mathrm{~J}$ & 9.0 & 9.0 & 0.9 & \\
& $957 \mathrm{~K}$ & 20.0 & 20.0 & 5.0 & \\
TAG-5 & $957 \mathrm{M}$ & 51.2 & 51.2 & 13.6 & \\
& $957 \mathrm{O}$ & 20.5 & 20.5 & 6.2 & \\
& $957 \mathrm{P}$ & 59.4 & 59.4 & 57.8 & \\
\hline
\end{tabular}

Notes: Data from Humphris, Herzig, Miller, et al. (1996). Holes 957D and 957L were abandoned with no recovery, and Holes 957E, F, G, H, and I were not cored over some intervals of basement penetration. Hole $957 \mathrm{~N}$ is a single wash core taken over the entire $42.2 \mathrm{~m}$ drilled section. Hole 957Q recovered only sand- to silt-sized (with pebbles) drill cuttings.

quartz \pm pyrite, which in some cases form vein nets, and with many of the quartz veins at least in part replacing basalt. Some silicified basalt clasts are cemented by gray, fine-grained, pyrite-bearing quartz veins, which are up to several centimeters wide and contain small fragments of silicified basaltic material. Veins of massive pyrite \pm chalcopyrite \pm quartz are present locally, particularly at TAG-4 and TAG-5. Late anhydrite veins are common, except at TAG-4, where anhydrite is notably absent. Broken surfaces of most rock fragments recovered from the stockwork have 1- to 2-mm-thick coatings of anhydrite, which are probably anhydrite veins along which the rocks broke during drilling. This suggests that anhydrite veins with predrilling widths of at least $1-2 \mathrm{~mm}$ are abundant throughout the stockwork.

At TAG-1, paragonitized basalt breccias occur below $101 \mathrm{mbsf}$ (Fig. 3). These are essentially identical to the silicified wallrock breccias, but are softer and appear less intensely silicified in hand specimen. Chloritized basalt breccias are present below 111 mbsf at TAG1. These rocks are altered to chlorite, quartz, and pyrite, and are green in hand specimen. Along abundant quartz + pyrite veins the green chloritized rocks are replaced first by gray paragonite + quartz + pyrite in centimeter-sized alteration halos, and then are more silicified toward the vein or breccia matrix.

The stockwork at TAG is zoned vertically and laterally. The siliceous stockwork begins at about 25-35 mbsf in the pyrite-silica breccias and continues downward in the silicified wallrock breccias, which contain the quartz + paragonite + pyrite assemblage (Fig. 3). Below 101 mbsf the rocks of the paragonitic stockwork are less silicified and contain the assemblage paragonite + quartz + pyrite. At 111 mbsf, the chloritic stockwork begins, with chlorite + quartz + pyrite and paragonite + quartz + pyrite assemblages.

Silicified wallrock breccias of the stockwork at TAG-1 and TAG2 are siliceous, whereas those at TAG- 4 and TAG-5, although they contain the same phases, are more pyritic. Massive pyrite is common, cementing and partly replacing altered basalt clasts at both sites, and at TAG-4 the clasts are noticeably less silicified. TAG-5 thus may be a pyritic variation of the siliceous stockwork, but TAG-4 probably represents a talus pile (Humphris et al., 1995). The altered basalt clasts at TAG- 4 are smaller and more rounded than at TAG-1, the silicified wallrock breccias at TAG-4 are clast supported and lack the pervasive quartz veining observed elsewhere, anhydrite is absent at TAG-4, and there is an abrupt transition downward to partly altered basalt, which suggest that the silicified wallrock breccias at TAG-4 are not part of the stockwork but rather represent a talus pile cemented by pyrite \pm quartz.

Basaltic basement penetrated at TAG-4 and in Hole 957B at TAG-2 constrains the width of the TAG stockwork near the surface to about $90 \mathrm{~m}$ (Fig. 3). At TAG-4, the basement consists of dark gray basalt with centimeter-sized green chloritized halos. Small amounts of chloritized glass and massive hydrothermal quartz probably represent interpillow material. The dark gray basalt is $5 \%-15 \%$ altered, with olivine, vesicles, and interstitial areas partly to totally altered or filled with smectite (saponite) and talc. The chloritic alteration halos are $60 \%-80 \%$ altered: olivine, pyroxene and interstitial areas and vesicles are replaced or filled by chlorite and mixed-layer chloritesmectite.

At TAG-2, basement consists of a 30-cm section of hydrothermally altered pillow breccia overlying slightly altered basalt. The breccia consists of millimeter- to centimeter-sized fragments of basalt and glass replaced by chlorite, cemented by chlorite and quartz, and stained red by iron oxide. A single centimeter-sized fragment of hydrothermal quartz cementing chloritized glass shards is also present. Pieces of basalt are dark gray and slightly altered, with smectite and iron oxyhydroxides replacing olivine and filling pores. Rimming some fragments are red alteration halos, $1-5 \mathrm{~mm}$ wide, where the rock is totally recrystallized to chlorite and stained red by iron oxide.

\section{SAMPLING AND METHODS}

Oxygen isotope ratios were measured on quartz separates and on bulk-rock powders. Quartz was separated from 25 samples representative of the various rock types and drill sites on the mound using variable combinations of hand picking and chemical techniques. Sulfide minerals were removed from quartz where necessary by dissolution in aqua regia. Samples of silicified basalt or samples containing such material were treated further by fusion with sodium pyrosulfate to remove phyllosilicates (Syers et al., 1968). Different morphologies of quartz were separated from three samples to check for heterogeneity among different generations of quartz. Quartz from the bulk silicified basalt clast, a typical white quartz vein, and late-stage prismatic quartz growing into a vug in the quartz vein were isolated from Sample 158-957C-14N-2, 22-27 cm. Quartz from a typical massive white quartz vein and late prismatic quartz were separated from Sample 158-957E-14R-1, 41-44 cm, and quartz from the bulk silicified basalt and from a massive white quartz vein were analyzed from Sample 158-957P-12R-2, 15-19 cm.

Fourteen whole-rock powders were analyzed for oxygen isotope ratios. These samples are splits of those which were also analyzed for major and trace elements (Humphris et al., Chap. 19, this volume) and for $\mathrm{Sr}$ contents and isotope ratios (Teagle et al., Chap. 22, this volume). Oxygen was extracted from quartz and whole-rock powders by reaction with $\mathrm{ClF}_{3}$ and converted to $\mathrm{CO}_{2}$ for analysis following the method of Clayton and Mayeda (1963). Results are reported in Table 2 as standard $\delta$ notation relative to SMOW. Replicate analyses of standards and samples were reproducible within $\pm 0.2 \%$ o.

\section{RESULTS AND DISCUSSION}

The results of this study provide constraints on temperatures and fluid compositions and their evolution in the subsurface, and are best discussed in terms of the general sequence of alteration of basement to form the stockwork beneath the TAG mound. The large-scale zonation from the chloritized margins and deep portion of the stockwork to the central paragonitized core (Fig. 3), as well as hand specimen zonations where chloritized rocks are rimmed by paragonitized halos and quartz-pyrite veins, indicate that early alteration involved conversion of basalt to chlorite \pm quartz \pm pyrite. Differences in the 
Table 2. Oxygen isotopic data for Leg 158 cores.

\begin{tabular}{|c|c|c|c|c|c|c|c|}
\hline Core, section, interval & Piece & Depth (mbsf) & $\begin{array}{l}\text { Bulk } \\
\delta^{18} \mathrm{O}\end{array}$ & $\begin{array}{l}\text { Quartz } \\
\delta^{18} \mathrm{O}\end{array}$ & $\begin{array}{c}\text { Temp. }{ }^{\circ} \mathrm{C} \\
(\text { fld }=1.7 \% o \text { ) }\end{array}$ & $\begin{array}{l}\text { Fluid } \delta^{18} \mathrm{O} \\
\left(\mathrm{T}=360^{\circ} \mathrm{C}\right)\end{array}$ & Sample \\
\hline \multicolumn{8}{|c|}{ TAG-1 Black Smoker Complex } \\
\hline \multicolumn{8}{|l|}{ 158-957C- } \\
\hline $7 \mathrm{~N}-1,34-36$ & $6 \mathrm{~B}$ & 19.84 & & 11.6 & 260 & 5.4 & Nodular siliceous py-anh breccia \\
\hline $10 \mathrm{~N}-1,17-20$ & 4 & 28.87 & & 11.1 & 273 & 4.9 & Py-anh breccia \\
\hline $14 \mathrm{~N}-2,22-27$ & $1 \mathrm{C}$ & 41.17 & & 8.6 & 339 & 2.3 & Bulk rock quartz; Si wr br \\
\hline $14 \mathrm{~N}-2,22-27$ & $1 \mathrm{C}$ & 41.17 & & 8.5 & 341 & 2.3 & Prismatic quartz; Si wr br \\
\hline $14 \mathrm{~N}-2,22-27$ & $1 \mathrm{C}$ & 41.17 & & 8.5 & 339 & 2.4 & White qz vein; Si wr br \\
\hline \multicolumn{8}{|l|}{$158-957 \mathrm{E}-$} \\
\hline $3 \mathrm{R}-1,16-19$ & 4 & 41.86 & & 10.4 & 289 & 4.2 & Py-si br; anh + py + cp vein \\
\hline $4 \mathrm{R}-1,18-20$ & 4 & 49.18 & & 8.1 & 352 & 1.9 & Si wr br; py + qz vein net \\
\hline $6 \mathrm{R}-1,11-13$ & 3 & 63.41 & & 9.8 & 302 & 3.6 & $\mathrm{Si}$ wr br; py + qz vein net \\
\hline $8 \mathrm{R}-1,15-20$ & 3 & 72.95 & & 11.4 & 265 & 5.2 & Si wr br; qz + py matrix; py + anh vein \\
\hline $11 \mathrm{R}-1,1-3$ & 1 & 87.11 & & 8.1 & 353 & 1.9 & Si wr br; qz + py vein net \\
\hline $14 \mathrm{R}-1,41-44$ & 10 & 101.90 & & 10.0 & 297 & 3.8 & White qz; paragonitized basalt breccia (silicified) \\
\hline $14 \mathrm{R}-1,41-44$ & & 101.90 & & 8.3 & 347 & 2.1 & Prismatic qz; paragonitized basalt breccia (silicified) \\
\hline $16 \mathrm{R}-1,9-13$ & 2 & 111.20 & & 8.8 & 331 & 2.6 & Paragonitized basalt $\mathrm{Br}, 20 \% \mathrm{qz}+$ py veins \\
\hline $16 \mathrm{R}-1,14-16$ & 3 & 111.25 & 7.1 & & & & Green chloritized basalt br, silicified, qz vein net \\
\hline $17 \mathrm{R}-1,18-22$ & 3 & 116.50 & & 7.9 & 359 & 1.7 & Grey paragonitized basalt br; py + qz vein net \\
\hline $18 \mathrm{R}-1,4-7$ & 1 & 120.75 & 2.1 & & & & Green chloritized basalt, $1 \%$ py veins \\
\hline $18 \mathrm{R}-1,20-24$ & 4 & 120.90 & 3.0 & & & & Green chloritized basalt, $1 \%$ py veins \\
\hline $18 \mathrm{R}-1,20-24$ & 4 & 120.90 & 10.1 & & & & Grey paragonitized basalt br, silicified, qz vein net \\
\hline $18 \mathrm{R}-1,45-47$ & 9 & 121.20 & 5.7 & & & & Green chloritized basalt br, $20 \%$ py + qz veins \\
\hline \multicolumn{8}{|l|}{ TAG-2 Kremlin } \\
\hline \multicolumn{8}{|l|}{ 158-957B- } \\
\hline $4 \mathrm{R}-1,17-24$ & 2 & 20.07 & 2.6 & & & & Red chloritized basalt \\
\hline $4 \mathrm{R}-1,39-41$ & 4 & 20.29 & 2.9 & & & & Chloritized glass fragments \\
\hline $4 \mathrm{R}-1,55-62$ & 8 & 20.45 & 5.9 & & & & Dark grey basalt (shipboard XRF powder) \\
\hline \multicolumn{8}{|r|}{ 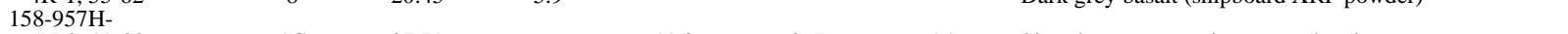 } \\
\hline $5 \mathrm{~N}-2,19-22$ & $1 \mathrm{C}$ & 27.79 & & 11.3 & 267 & 5.1 & Si wr br; qz + py vein; py + anh vein \\
\hline $6 \mathrm{~N}-1,36-38$ & 6 & 31.56 & & 17.2 & 172 & 11.0 & Nodular py-si-anh br; py + anh vein; chalcedony vugs \\
\hline $9 X-1,1-3$ & 1 & 45.00 & & 8.3 & 347 & 2.1 & Si wr br; qz + py vein net; py + anh vein \\
\hline \multicolumn{8}{|r|}{ Si } \\
\hline $1 \mathrm{~W}-1,20-23$ & 3 & 0.20 & & 10.3 & 290 & 4.1 & Py-si br; multiple breccia; $\mathrm{ZnS}$ coating \\
\hline \multicolumn{8}{|l|}{ TAG-3 South } \\
\hline 1R-CC, $1-13$ & & 5.68 & & 11.7 & 259 & 5.5 & Red quartz + Fe-oxide cuttings \\
\hline \multicolumn{8}{|l|}{ TAG-4 West } \\
\hline $158-957 \mathrm{I}-$ & & & & & & & \\
\hline $1 \mathrm{~N}-1,69-73$ & 11 & 9.69 & & 13.7 & 223 & 7.4 & Intensely silicified basalt br, qz vein net \\
\hline \multicolumn{8}{|r|}{ 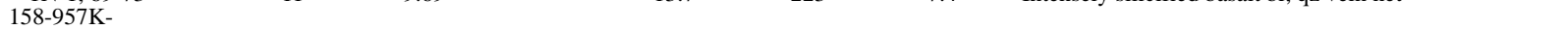 } \\
\hline \multirow{2}{*}{\multicolumn{8}{|c|}{$158-957 \mathrm{M}-$}} \\
\hline & & & & & & & \\
\hline $3 \mathrm{R}-1,19-21$ & 5 & 14.49 & & 10.7 & 280 & 4.5 & Si wr br; py + qz vein net \\
\hline $5 \mathrm{R}-1,22-24$ & 6 & 24.52 & & 8.7 & 336 & 2.4 & Si wr br; qz + py vein net \\
\hline $7 \mathrm{R}-1,24-27$ & 5 & 34.54 & & 8.2 & 351 & 2.0 & Paragonitized (+py) basalt; qz + py vein; massive py vein \\
\hline 9R-1, 32-37 & 6 & 42.62 & 4.5 & & & & Green chloritic alteration halo \\
\hline $9 \mathrm{R}-1,32-37$ & 6 & 42.62 & 5.9 & & & & Dark grey host rock \\
\hline $10 \mathrm{R}-1,30-32$ & 5 & 46.51 & 6.7 & & & & Dark grey basalt \\
\hline $10 \mathrm{R}-1,33-36$ & 6 & 46.53 & 6.8 & & & & Dark grey basalt (shipboard XRF powder) \\
\hline $10 \mathrm{R}-1,123-125$ & 17 & 47.43 & & 9.5 & 312 & 3.3 & Massive interpillow hydrothermal quartz \\
\hline $10 \mathrm{R}-1,142-143$ & 21 & 47.80 & 6.4 & & & & Dark grey basalt \\
\hline $10 \mathrm{R}-1,142-143$ & 21 & 47.80 & 5.2 & & & & Green chloritic alteration halo \\
\hline \multicolumn{8}{|l|}{$\begin{array}{l}\text { TAG-5 North } \\
158-957 \mathrm{P} \text { - }\end{array}$} \\
\hline $8 \mathrm{R}-1,5-7$ & 2 & 35.15 & & 8.1 & 355 & 1.9 & Si wr br, intensely silicified, $\mathrm{qz}+$ py vein net \\
\hline $10 \mathrm{R}-1,3-4$ & 1 & 45.13 & & 8.8 & 331 & 2.6 & Silicified basalt clast \\
\hline $12 \mathrm{R}-2,15-19$ & 4 & 55.79 & & 8.8 & 331 & 2.6 & Grey qz; si wr br; multiple breccia \\
\hline $12 \mathrm{R}-2,15-19$ & 4 & 55.79 & & 9.0 & 324 & 2.8 & White qz; si wr br; multiple breccia \\
\hline
\end{tabular}

Notes: $\delta^{18} \mathrm{O}$ in $\%$ o SMOW. Temperatures were calculated assuming equilibrium with hydrothermal fluid having $\delta^{18} \mathrm{O}=1.7 \% \circ($ Shanks et al., 1995$)$, and fluid $\delta^{18} \mathrm{O}$ calculated assuming equilibrium at $360^{\circ} \mathrm{C}$, the temperature of end-member black smoker vent fluids (Edmond et al., 1995), using the empirical quartz-water oxygen isotopic fractionation factor from Sharp and Kirschner (1994). S = section; bot = bottom; pc = piece; Si wr br = siliceous wallrock breccia; $b r=$ breccia; $p y=$ pyrite; anh = anhydrite; qz = quartz; fld = fluid.

compositions of chlorite and the isotopic ratios of $\mathrm{Sr}$ from whole rocks indicate that chloritization processes varied among the different sites beneath the mound (the deep chloritic stockwork, shallow basement beneath the mound margins at TAG-1 and at TAG-2; Alt, unpubl. data; Teagle et al., Chap. 22, this volume). The chlorite-rich assemblages were subsequently replaced by paragonite + quartz + pyrite to form the main paragonitic stockwork via reaction with upwelling hydrothermal fluids that were depleted in $\mathrm{Mg}$ and enriched in alkalis, similar to those venting at the seafloor (Von Damm, 1995). The rocks then underwent continued silicification and pyritization, with precipitation of quartz + pyrite in veins. Finally, anhydrite formed in veins as seawater was heated and mixed with hydrothermal fluids during penetration into the subsurface, to depths of at least 125 m (Teagle et al., Chap. 11, this volume; Mills et al., Chap. 10, this volume). Sulfur and oxygen isotopic analyses of anhydrite indicate that small amounts of sulfate reduction occurred prior to anhydrite precipitation, however (Chiba et al., Chap. 6, this volume). Results of oxygen isotopic analyses are given in Table 2, and are discussed below in terms of the processes outlined above.

\section{Basement Beneath Mound Margins}

Samples of slightly altered dark gray basalt from beneath the margins of the mound at TAG-2 and TAG-4 and centimeter-sized chloritized alteration halos in the dark gray basalts from TAG-4 were analyzed. Five samples of dark gray basalt cluster about $6 \%$ and do not 
contain chlorite (Fig. 4; Table 2). Two of these rocks have primary $\delta^{18} \mathrm{O}$ values $\left(5.9 \%\right.$ ), whereas the others are slightly enriched in ${ }^{18} \mathrm{O}$ $(6.4 \%$ - $6.8 \%$ ) as the result of low-temperature smectitic alteration (Muehlenbachs and Clayton, 1972). The small amounts of smectite in these samples (about 10\%) require high $\delta^{18} \mathrm{O}$ values for smectite ( $15 \%$ o to account for a bulk-rock value of $6.7 \%$ o), indicating low temperatures of alteration, less than about $100^{\circ} \mathrm{C}$ (Savin and Lee, 1988). Some of these rocks from TAG-4 have millimeter-wide red oxidation halos, similar to those observed in "weathered" basalts (Alt, 1995) superimposed on chloritization halos, suggesting that the low-temperature alteration postdated chloritization and waning of high-temperature activity at this site.

Compared to the fresh and slightly altered host rocks, the chloritized alteration halos at TAG-4 have lower $\delta^{18} 0$ values $(4.6 \%$ o- $5.2 \%$; Fig. 4). The chloritized halos are enriched in $\mathrm{Zn}$ and $\mathrm{S}$, have gained only small amounts of $\mathrm{Mg}$, contain Fe-chlorite (chamosite), and have ${ }^{87} \mathrm{Sr} /{ }^{86} \mathrm{Sr}$ ratios midway between mid-ocean-ridge basalt and hydrothermal fluids, indicating reaction with hydrothermal fluids (J. Alt, unpubl. data; Humphris et al., Chap. 19, this volume; Teagle et al., Chap. 22, this volume). Quartz occurs with sulfide in veins through chloritized basalt and as massive, interpillow hydrothermal quartz at the base of Hole 957M at TAG-4, and oxygen isotopic analysis of the interpillow quartz suggests a temperature of about $310^{\circ} \mathrm{C}$ for the chloritization reactions involving hydrothermal fluids (Table 2; see below).

A sample of chloritized glass and a chloritized basalt from basement beneath the mound margin at TAG- 4 have $\delta^{18} \mathrm{O}$ values of $2.9 \%$ o and $2.6 \%$, respectively (Table 2; Fig. 4). Several lines of evidence indicate that chloritization at TAG-4 proceeded via reaction of unreacted seawater with basalt: the chlorites are the most magnesian chlorites reported from the seafloor $\left(\mathrm{Fe} / \mathrm{Fe}+\mathrm{Mg}_{\text {molar }}=0.16\right.$; J. Alt and $\mathrm{J}$. Honnorez, unpubl. data); chloritization of basaltic glass resulted in a near-tripling of the $\mathrm{MgO}$ content of the rock (Humphris et al., Chap.

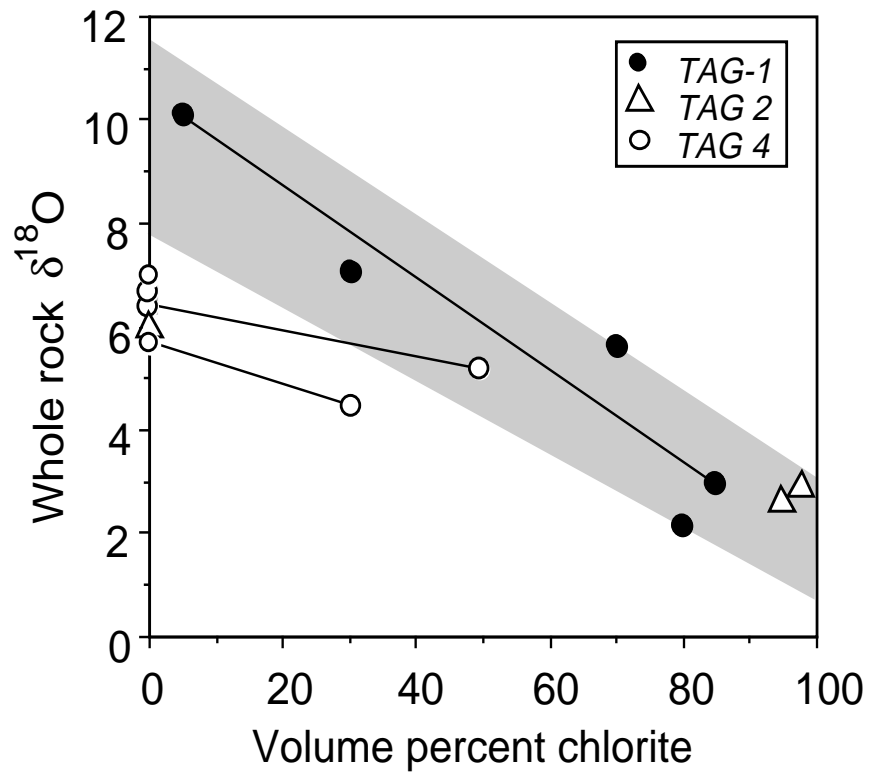

Figure 4 . Whole-rock $\delta^{18} \mathrm{O}$ vs. volume percent chlorite. Lines connect adjacent alteration zones from the same sample. Chloritized halos from TAG-4 have lower $\delta^{18} \mathrm{O}$ than unaltered basalt $(5.9 \%$ ) and chlorite-free basalts altered at low temperatures. Samples from TAG-1 and TAG-2 that contain $>60 \%$ chlorite are bimodal mixtures of chlorite and quartz and fall on a mixing trend (shaded area) between stockwork quartz (7.9\%o-11.7\%o) and chlorite (estimated to be $1 \% \sigma_{-3}-3 \%$ ). Samples containing $<60 \%$ chlorite also contain other phases in addition to quartz and chlorite and cannot be used to constrain chlorite composition. Volume percent chlorite from visual estimates in thin sections.
19, this volume); and the chloritized rocks have $\mathrm{Sr}$ isotope ratios approaching that of seawater (Teagle et al., Chap. 22, this volume). Using the chlorite-water oxygen isotope fractionation factor of Wenner and Taylor (1971) and assuming pure chlorite in equilibrium with seawater having $\delta^{18} \mathrm{O}=0 \%$, the measured $\delta^{18} \mathrm{O}$ values give calculated temperatures of formation of $180^{\circ}-190^{\circ} \mathrm{C}$. These are minimum values, as the samples are mixtures of chlorite with small amounts $(<5 \%)$ of $\mathrm{Fe}$ oxyhydroxides that formed during superimposed lowtemperature oxidation (Humphris, Herzig, Miller, et al., 1996), and seawater hydrothermal fluids are commonly enriched in ${ }^{18} \mathrm{O}(1.7 \%$ at TAG; Shanks et al., 1995). Taking these effects into account would tend to increase the calculated temperatures of formation. The $\mathrm{Mg}$ rich chlorite and whole-rock gains of $\mathrm{Mg}$ indicate that fluids were seawater or at most partly reacted seawater, rather than $\mathrm{Mg}$-depleted hydrothermal fluids. Assuming a fluid $\delta^{18} \mathrm{O}$ of $1 \%$, intermediate between seawater and hydrothermal vent fluids, gives a calculated temperature of about $250^{\circ} \mathrm{C}$ for the TAG-4 chlorite.

A tripling of the $\mathrm{MgO}$ content of the chloritized glass from TAG4 (Humphris et al., Chap. 19, this volume) gives an integrated seawater/rock mass ratio of 85 , assuming all $\mathrm{Mg}$ was extracted from seawater to form the chlorite. This is a minimum amount of seawater, however, as the calculation assumes quantitative extraction of $\mathrm{Mg}$ from the fluid and does not consider reaction with seawater that had already lost some $\mathrm{Mg}$.

The chloritized basaltic material beneath the margins of the mound provides evidence for heating of seawater (at TAG-2) and flow of high-temperature fluids in the subsurface at least to the edge of the mound (at TAG-4), consistent with the presence of high heat flow through sediments and inferred hydrothermal flow to the west and north of the mound (Becker and Von Herzen, 1996). Very similar rocks exhibiting chloritization halos have also been sampled from a debris flow at the northeast margin of the mound (Masuda et al., 1995), suggesting that this type of hydrothermal flow and alteration is typical beneath the margins of the mound.

\section{Deep Chloritized Stockwork}

Although chlorite was not separated and analyzed directly, the oxygen isotopic composition of chlorite in the deep chloritized stockwork at TAG-1 can be estimated from whole-rock data. Figure 4 shows the $\delta^{18} \mathrm{O}$ of whole rocks vs. the amount of chlorite in the rock. Samples from TAG-1 that contain $>50 \%$ chlorite contain quartz and chlorite as essentially the only oxygen-bearing phases and can be considered two-component mixtures, whereas the other TAG-1 samples and the chloritized halos from TAG-4 contain other phases (paragonite, pyroxene, plagioclase) as well, and cannot. Quartz from the TAG stockwork has $\delta^{18} \mathrm{O}$ values of $7.9 \%$ o-11.7\% (Table 1; Fig. 5A), so extending a swath from quartz at $0 \%$ chlorite, $\delta^{18} \mathrm{O}=7.9 \% 0^{-}$ $11.7 \%$, through the chlorite-rich TAG-1 samples on Figure 4 to $100 \%$ chlorite can give an estimate of chlorite composition. The $\delta^{18} \mathrm{O}$ of chlorite estimated this way ranges from $1 \%$ o to $3 \%$. Similar values have been reported for highly chloritized rocks from a debris flow at the northeast margin of the TAG mound (Masuda et al., 1995), presumably reflecting the similar temperatures and fluids.

Chlorites in the chloritized rocks from the deep stockwork at TAG-1 (121-127.5 mbsf) are clinochores with $\mathrm{Fe} / \mathrm{Fe}+\mathrm{Mg}_{\text {molar }}=$ $0.25-0.5$, and whole rocks have gained $\mathrm{Mg}$ (J. Alt and J. Honnorez, unpubl. data; Humphris et al., Chap. 19, this volume): a $60 \%$ increase in $\mathrm{MgO}$ content is calculated from $\mathrm{MgO}_{\text {chlorite }}=17 \mathrm{wt} \%, \mathrm{MgO}_{\text {fresh basalt }}$ $=8.8 \mathrm{wt} \%$, chloritized basalt $=80 \%$ chlorite $+15 \%$ quartz $+5 \%$ pyrite (J. Alt, unpubl. data; Humphris, Herzig, Miller, et al., 1996). This $\mathrm{Mg}$ increase might be taken to indicate significant involvement of seawater as at TAG-2, but ${ }^{87} \mathrm{Sr} /{ }^{86} \mathrm{Sr}$ ratios of the chloritized and paragonitized rocks from throughout the TAG-1 central stockwork have uniform values (0.7038-0.7042; Teagle et al., Chap. 22, this volume), which are similar to the ratio for present-day vent fluids (0.7038; Edmond et al., 1995). If altering fluids comprised mixtures of hydro- 


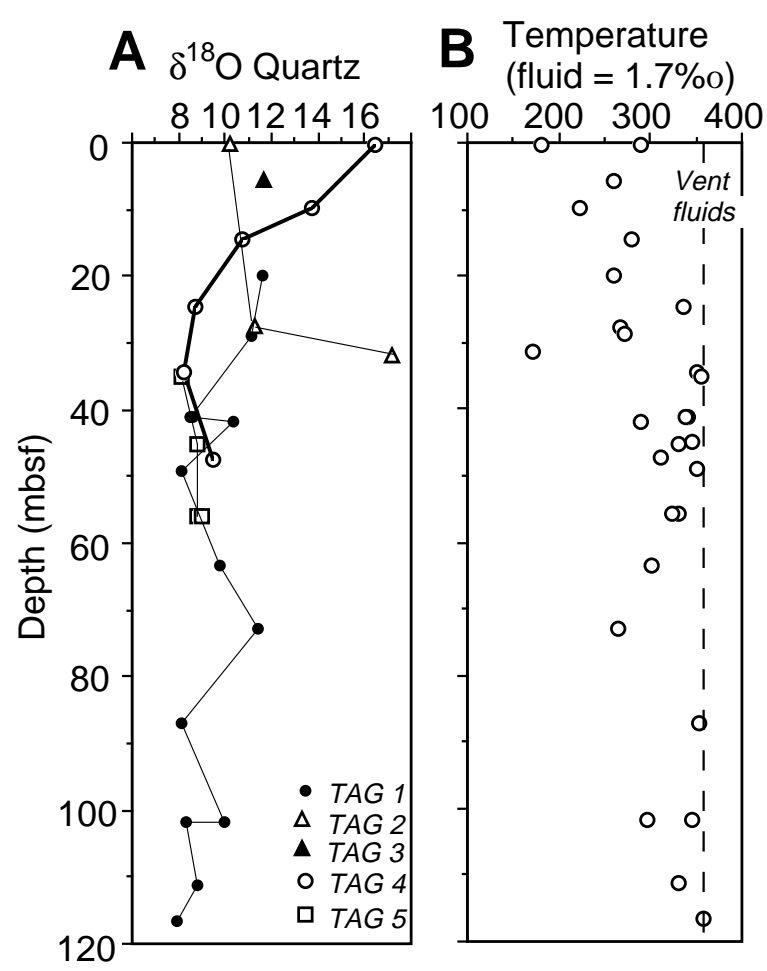

Figure 5. Oxygen isotopic data for quartz from TAG drill core. A. $\delta^{18} \mathrm{O}$ values of quartz from Table 2. Lines connect samples from the same area (e.g., TAG-1, TAG-2, etc.) B. Temperatures calculated assuming equilibrium with hydrothermal fluid having $\delta^{18} \mathrm{O}=1.7 \%$ (Sharp and Kirschner, 1994; Shanks et al., 1995). Dashed vertical line is temperature of end-member black smoker vent fluids at TAG (Edmond et al., 1995).

thermal fluid $\left.{ }^{87} \mathrm{Sr} /{ }^{86} \mathrm{Sr}=0.7038\right)$ and seawater $(0.7091)$, then the whole-rock $\mathrm{Sr}$ isotope ratios of the central stockwork indicate that less than $10 \%$ of a seawater component was present. Thus, $<10 \%$ seawater was involved in chloritization reactions in the deep chloritic stockwork. Assuming 10\% seawater and 90\% Mg-depleted hydrothermal fluid in the chloritizing fluids (and correspondingly low fluid $\mathrm{Mg}$ concentration) implies integrated water/rock mass ratios of $\sim 280$ for the chlorite-rich rocks from the deep stockwork (assuming total extraction of $\mathrm{Mg}$ from the fluid during chloritization).

The ${ }^{87} \mathrm{Sr} /{ }^{86} \mathrm{Sr}$ ratios of the deep chloritized stockwork rocks from TAG range down to 0.70385 , identical to the hydrothermal vent fluids (0.7038; Edmond et al., 1995) and suggesting that essentially no seawater was present in these chloritizing fluids. Sampled hydrothermal vent fluids are typically contaminated to various degrees with ambient seawater entrained during sampling, so samples are assumed to be two-component mixtures of seawater with hydrothermal fluid and are extrapolated to $\mathrm{Mg}$-free compositions in order to estimate the hydrothermal end-member (Von Damm, 1995; Edmond et al., 1995; Shanks et al., 1995). The assumption of a zero-Mg fluid is reasonable to estimate the hydrothermal concentrations of most elements, but if upwelling hydrothermal fluids are in equilibrium with chlorite in a deep reaction zone, then the fluids should contain some magnesium ( 1 mmol Mg/kg; Saccocia and Seyfried, 1994; Edmond et al., 1995). At these $\mathrm{Mg}$ contents the fluids would fall within the chlorite stability field at $300^{\circ}-350^{\circ} \mathrm{C}$ (Saccocia and Seyfried, 1994) and could result in chloritization of basalts. Assuming the $\mathrm{Mg}$ increase in the deep chloritized stockwork at TAG-1 resulted from total extraction of $\mathrm{Mg}$ from hydrothermal fluids containing $1 \mathrm{mmol} \mathrm{Mg} / \mathrm{kg}$ gives an integrated fluid/rock mass ratio of 1400 . Temperatures of $250^{\circ}-350^{\circ} \mathrm{C}$ are calculated for chlorite from the deep stockwork, using chlorite $\delta^{18} \mathrm{O}$ values of $1 \%$ o-3\%o estimated from Figure 4, the chlorite-water fractionation factor of Wenner and Taylor (1971), and assuming equilibrium with hydrothermal fluids having $\delta^{18} \mathrm{O}$ equal to black smoker vent fluids from the TAG mound (1.7\%o; Shanks et al., 1995).

\section{The Main Paragonitic Stockwork and Mound}

The main portion of the TAG stockwork consists of the paragonite + quartz + pyrite assemblage, which formed via replacement of previously chloritized basalts. The formation of paragonite requires very low $\mathrm{Mg}$ concentrations in solution (Saccocia and Seyfried, 1994), such as the Mg-depleted and alkali-enriched hydrothermal fluids venting from black smokers atop the mound (Edmond et al., 1995; Von Damm, 1995). Sr isotope ratios of paragonitized stockwork rocks are uniform and very close to present-day vent fluids, consistent with origin of these rocks by reaction with hydrothermal fluids (Teagle et al., Chap. 22, this volume). The TAG vent fluids have a relatively high $\mathrm{Na} / \mathrm{K}$ ratio compared to other seafloor vents (Von Damm, 1995), which accounts for the formation of paragonite in the stockwork, rather than muscovitic sericite. Quartz is a major component of the paragonitized rocks and occurs in abundant quartz \pm pyrite veins throughout the main stockwork. Thus oxygen isotopic constraints on quartz formation can help further our understanding of the development of the main paragonitic stockwork zone.

Quartz from throughout the mound and underlying basement has $\delta^{18} \mathrm{O}$ values mostly in the range from $7.9 \%$ o to $11.7 \%$ ( 26 samples), but three mound samples have higher values of $13.7 \%$ o-17.2\%o (Table 2; Fig. 5A). Quartz in breccias from within the mound (the upper $\sim 30 \mathrm{~m})$ generally has higher values $(>10.5 \%$ o $)$ than do deeper samples from silicified clasts or wallrock breccias, and TAG-4 quartz exhibits a progressive increase in $\delta^{18} \mathrm{O}$ upward from the stockwork through the mound (Fig. 5A).

The oxygen isotopic composition of hydrothermal quartz precipitated in equilibrium with a solution is a function of the isotopic composition of the fluid as well as the temperature dependent mineralwater isotopic fractionation (Clayton et al., 1972). At TAG, hydrothermal fluids venting at black smokers have temperatures of $360^{\circ}-$ $365^{\circ} \mathrm{C}$ and $\delta^{18} \mathrm{O}=1.7 \%$ (Edmond et al., 1995; Shanks et al., 1995). Using the experimentally determined quartz-water fractionation of Clayton et al. (1972) and the vent fluid composition of $1.7 \%$ gives calculated temperatures of $150^{\circ}-320^{\circ} \mathrm{C}$, significantly less than that of the measured vent fluids. This could be attributed to precipitation of quartz via cooling of hydrothermal fluids, and/or to ${ }^{18} \mathrm{O}$-enrichment of fluids via interaction with host rocks within the stockwork. These processes undoubtedly occurred, but quartz is saturated in the vent fluids and at least some quartz would be expected to precipitate at temperatures approaching that of the vent fluids (Tivey et al., 1995). Moreover, fluid $\delta^{18} \mathrm{O}$ values at least twice those of the vent fluids would be required for the analyzed quartz to yield calculated temperatures equal to the vent fluids $\left(360^{\circ} \mathrm{C}\right)$, in turn requiring significant fluid-rock interaction beneath the mound (see following section).

If the empirical oxygen isotopic fractionation between quartz and water from Sharp and Kirschner (1994) is used, however, the temperatures calculated for quartz formation are more consistent with measured vent fluid temperatures and isotopic compositions. Using this fractionation factor, the $\delta^{18} \mathrm{O}$ values of quartz yield calculated temperatures of $170^{\circ}-360^{\circ} \mathrm{C}$ (assuming equilibrium with hydrothermal fluids, $\delta^{18} \mathrm{O}=1.7 \%$ ), with most of the calculated values falling in the range from $260^{\circ}$ to $360^{\circ} \mathrm{C}$ (Fig. 5B; Table 2). The maximum temperatures estimated for quartz using the present vent fluid isotopic compositions agree with measured black smoker temperatures of $360^{\circ}-$ $365^{\circ} \mathrm{C}$ (Table 2; Fig. 5B; Edmond et al., 1995). The scatter to lower calculated temperatures is consistent with precipitation of quartz during cooling and mixing of hydrothermal fluids with seawater within and beneath the mound. It is likely that limited ${ }^{18} \mathrm{O}$-enrichment of hydrothermal fluids occurred via fluid-rock interaction within the shallow upflow zone: use of fluid $\delta^{18} \mathrm{O}$ values greater than present vent fluid values in the calculations would result in slightly higher calcu- 
lated temperatures and reduce the scatter to lower temperatures in Figure 5B. While use of the empirical quartz-water fractionation factor is still somewhat controversial (Sharp and Kirschner, 1994), its application at TAG gives geologically more reasonable results where the usual unknown variables (temperature and fluid composition) have been measured directly.

Despite the probable local increases of fluid $\delta^{18} \mathrm{O}$ through fluidrock interactions and the effect this would have on the calculated temperatures in Figure 5B (i.e., higher temperatures), the scatter to lower calculated temperatures for many quartz samples in Figure 5B must be real. Lower temperatures of $170^{\circ}-180^{\circ} \mathrm{C}$ calculated for two mound breccias (Table 2; Fig. 5B) are reasonable, as these samples contain microcrystalline $(1-10 \mu \mathrm{m})$ quartz with pyrite \pm chalcedony \pm sphalerite, and are similar to lower temperature surficial deposits (Tivey et al., 1995). These textures are in contrast to the well-developed coarser (hundreds of micrometers) quartz present throughout the TAG cores.

There is a general increase in $\delta^{18} \mathrm{O}$ upward from the stockwork into the mound (above $\sim 30 \mathrm{mbsf} ;$ Fig. $5 \mathrm{~A}$ ). Quartz from the mound has a mean $\delta^{18} \mathrm{O}$ of $12.3 \% \circ( \pm 2.7 \% \circ 1 \sigma)$ vs. $8.9 \% \circ+0.9 \%$ ( $\left.1 \sigma\right)$ for stockwork quartz. Assuming constant fluid compositions, this indicates lower temperatures in the mound, which may be the result of cooling of the mound by seawater entrained into the mound. This interpretation is consistent with various other evidence indicating the movement of significant amounts of seawater through the mound, including the compositions of white smoker fluids, the presence of abundant anhydrite within the mound, locally very low heat flow values on the surface of the mound, and common low-temperature diffuse flow of fluids out of the mound (Humphris, Herzig, Miller, et al., 1996; Edmond et al., 1995; Tivey et al., 1995; Becker and Von Herzen, 1996; Mills et al., 1996). Although fluid $\delta^{18} \mathrm{O}$ values within the mound probably varied slightly, the agreement of the lower calculated temperatures for quartz formation within the mound with various other evidence indicating cooling of the mound by seawater suggests that the calculated lower temperatures in the mound are significant.

\section{Origin of Fluids}

The hydrothermal fluids venting at seafloor black smokers are interpreted to result from progressive reactions in recharge and deep high-temperature $\left(350^{\circ}-400^{\circ} \mathrm{C}\right)$ reaction zones (e.g., Alt, 1995; Shanks et al., 1995; Bowers and Taylor, 1985; Seyfried and Ding, 1995). Seawater reacting with basalts at low temperatures $\left(<150^{\circ} \mathrm{C}\right)$ during recharge may be slightly depleted in ${ }^{18} \mathrm{O}$, but then becomes progressively enriched in ${ }^{18} \mathrm{O}$ via high-temperature $\left(>250^{\circ} \mathrm{C}\right)$ interaction with basaltic crust at depth (Bowers and Taylor, 1985). These hot, ${ }^{18} \mathrm{O}$-enriched fluids $(\sim 2 \%$ ) then rise rapidly to vent at the seafloor and undergo only small amounts of cooling and little interaction with wallrocks, leaving behind a reservoir of ${ }^{18} \mathrm{O}$-depleted rocks in the middle and lower crust (Muehlenbachs and Clayton, 1976; Bowers and Taylor, 1985; Seyfried and Ding, 1995).

There are several reactions that could conceivably produce further ${ }^{18} \mathrm{O}$ enrichments of upwelling hydrothermal fluids in the TAG stockwork zone, but reaction of basalt to chlorite- or paragonite-rich assemblages are the most likely. There is some evidence for variable oxygen isotopic compositions of quartz within individual samples, which could reflect variations in both fluid compositions and temperature: late prismatic quartz from Sample 158-957E-14R-1, 41-44 $\mathrm{cm}$, has a lower $\delta^{18} \mathrm{O}$ value (8.3\%o) than the typical granular white quartz vein (10.0\%o; Table 2 ). The other samples analyzed, however, do not display heterogeneity at this level (Samples 158-957C-14N-2, 22-27 cm, and 158-957P-12R-2, 15-19 cm; Table 2).

Paragenetic relationships indicate replacement of the chloritic stockwork assemblage by the paragonitic assemblage, but this reaction will not produce ${ }^{18} \mathrm{O}$-enriched fluids. Because of the greater frac- tionation of ${ }^{18} \mathrm{O}$ into paragonite compared to chlorite at constant temperature, reaction of chloritized basalt having $\delta^{18} \mathrm{O} \approx 3 \%$ o with a hydrothermal fluid $\left(1.7 \%\right.$ o ) to form paragonite at $<375^{\circ} \mathrm{C}$ results in an increase in $\delta^{18} \mathrm{O}$ of the rock and a corresponding decrease in the $\delta^{18} \mathrm{O}$ of the fluid. However, reaction of partly chloritized or unaltered basalt, such as that at the base of TAG-4 $\left(\delta^{18} \mathrm{O}_{\text {rock }}=4.5 \%-5.8 \%\right.$ ), with hydrothermal fluid to produce paragonite can result in fluid ${ }^{18} \mathrm{O}$ enrichments at water/rock mass ratios less than $\sim 5$ and temperatures $>300^{\circ} \mathrm{C}$ (Fig. 6). A problem with this reaction is that it requires that high-temperature hydrothermal fluids come into contact with relatively unaltered basalt, which presumably must take place somewhere within the present paragonitic stockwork.

The uptake of $\mathrm{Mg}$ by the rocks during chloritization and the $\mathrm{Sr}$ and $\mathrm{O}$ isotope ratios of chloritized rocks require high integrated water/ rock mass ratios during chloritization (at least 30-300; Table 2; Humphris et al., Chap. 19, this volume; Teagle et al., Chap. 22, this volume). Such reactions will produce the observed low $\delta^{18} \mathrm{O}$ values of the chloritized rocks, but will not result in the ${ }^{18} \mathrm{O}$ enrichments of hydrothermal fluids (Fig. 7). Only the initial reaction of seawater with basalt to chlorite at very low water/rock ratios during entrain-
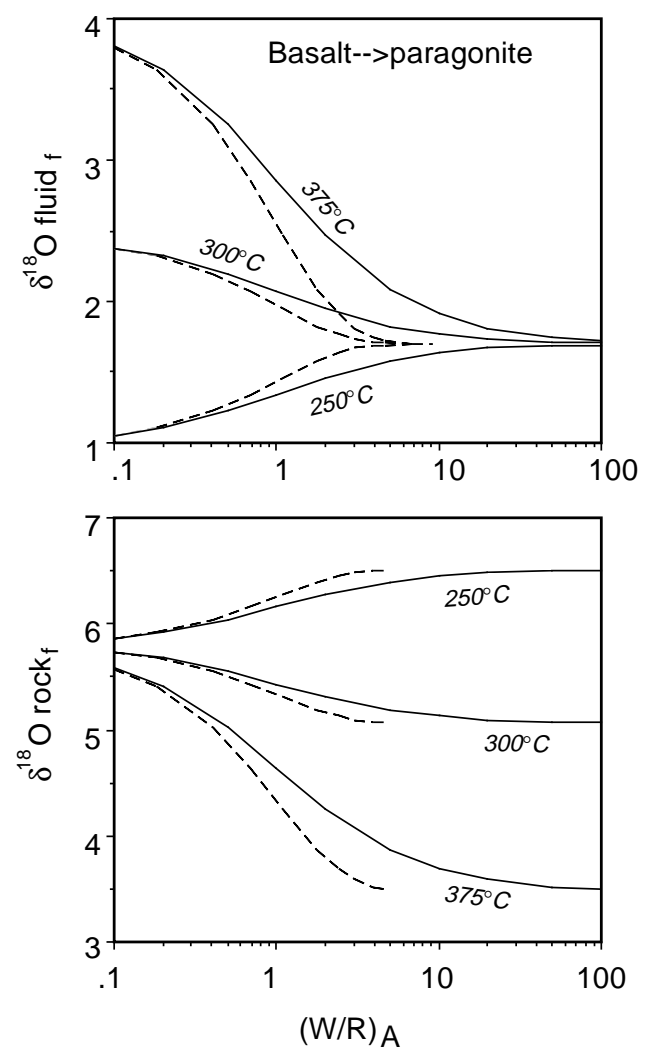

Figure 6. Oxygen isotopic compositions of fluid and rock for reaction of basalt to paragonite. Calculations made using the equation of Taylor (1977): $(\mathrm{W} / \mathrm{R})_{\mathrm{A}}=\left(\delta_{\mathrm{r}}{ }^{\mathrm{f}}-\delta_{\mathrm{r}}^{\mathrm{i}}\right) /\left(\delta_{\mathrm{w}}{ }^{\mathrm{i}}-\delta_{\mathrm{w}}{ }_{\mathrm{f}}\right)$, where $\delta_{\mathrm{r}}{ }^{\mathrm{i}}=\delta^{18} \mathrm{O}$ initial rock, $\delta_{\mathrm{r}}{ }^{\mathrm{f}}=\delta^{18} \mathrm{O}$ final rock, $\delta_{\mathrm{w}}{ }^{\mathrm{i}}=\delta^{18} \mathrm{O}$ initial fluid, $\delta_{\mathrm{w}}{ }^{\mathrm{f}}=\delta^{18} \mathrm{O}$ final fluid. Calculations used the muscovite-water isotopic fractionation factor from Friedman and O'Neil (1977), and were made for $\delta_{\mathrm{r}}{ }^{\mathrm{i}}=5.8 \%$, using $\delta_{\mathrm{w}}{ }^{\mathrm{i}}=1.7 \%$ o (hydrothermal fluid) for closed (solid lines) and open (dashed lines) systems, where $(W / R)_{A}$ open $=\ln \left[1+(\mathrm{W} / \mathrm{R})_{\text {closed }}\right] .(\mathrm{W} / \mathrm{R})_{\mathrm{A}}$ is the atomic water/rock ratio (Stakes and O'Neil, 1982), which is twice as large as the water/rock mass ratio calculated by other means (e.g., Mg uptake by the rock). The diagrams illustrate that reaction of hydrothermal fluid with basalt to form paragonite can result in fluid ${ }^{18} \mathrm{O}$ enrichments. Similar results are obtained if partly chloritized basalt $\left(\delta^{18} \mathrm{O}_{\text {rock }}=4.5 \%\right.$ o is used in the calculations. 
ment of seawater into the margins of the stockwork would produce a small amount of highly ${ }^{18} \mathrm{O}$-enriched fluids (Fig. 7). This scenario would require input of partly reacted seawater into the subsurface beneath the TAG mound to produce ${ }^{18} \mathrm{O}$-enriched fluids for quartz formation. Despite the evidence for this process (chloritized basalt, anhydrite veins), Sr isotopic data suggest that, with the exception of anhydrite veins, most of the main stockwork has essentially equilibrated with present-day end-member hydrothermal fluids, and that shallow reactions in the stockwork do not significantly influence the vent fluids (Teagle et al., Chap. 22, this volume). On the other hand, diffuse flow of fluids out of the mound reflects significant reactions within and perhaps beneath the mound, but Mg behaves conservatively in these fluids and at present there is no evidence for chloritization in the source of the diffuse fluids (Mills et al., 1996; James et al., 1996).

\section{SUMMARY AND CONCLUSIONS}

The TAG hydrothermal mound consists of various breccias that commonly contain quartz, and the underlying stockwork is zoned, from a central quartz + paragonite + pyrite core, to a deep chlorite + quartz + pyrite zone and marginal chloritic zones. Oxygen isotope analyses were carried out on 29 quartz separates and 14 whole rocks from the mound and underlying stockwork. Basement recovered from beneath the eastern (TAG-2) and western (TAG-4) margins of the mound ranges from fresh basalt $\left(\delta^{18} \mathrm{O}=5.9 \%\right.$ o), to basalt affected by low-temperature $\left(<100^{\circ} \mathrm{C}\right)$ smectitic alteration $\left(6.4 \% 0^{-}-6.8 \% o\right)$, and partly to totally chloritized basalts $\left(2.1 \% 0_{-}-5.5 \%\right)$. Chloritization at TAG-4 occurred via reaction of rocks with hydrothermal fluids, and at TAG-2 by reaction of basalt with seawater at integrated seawater/ rock ratios of at least 30 . Temperatures of chloritization estimated from $\delta^{18} \mathrm{O}$ of chlorite and associated quartz are $\sim 250^{\circ}-310^{\circ} \mathrm{C}$. The chloritized rocks at the edges of the mound are evidence for heating and flow of high-temperature fluids in the subsurface beyond the margins of the mound, consistent with inferences from heat flow observations for hydrothermal activity away from the mound. The lowtemperature smectitic alteration of basalts beneath the mound probably followed waning of high-temperature activity at these locations.

Chlorite from the deep chloritic stockwork has $\delta^{18} \mathrm{O}$ values of $1 \%$ - $3 \%$, and whole-rock values are $2.1 \%$ - $-5.7 \%$ o. Chloritization in the deep stockwork proceeded via reaction of basalt with hydrothermal fluids containing $<10 \%$ seawater component at temperatures of $\sim 250^{\circ}-350^{\circ} \mathrm{C}$ and at integrated water/rock mass ratios of at least 300 .

Chloritization by early $\mathrm{Mg}$-bearing hydrothermal fluids was followed by reaction of the chloritized rocks with $\mathrm{Mg}$-depleted, alkalienriched hydrothermal fluids having elevated $\mathrm{Na} / \mathrm{K}$ ratios to produce the paragonite + quartz + pyrite assemblage characteristic of the main TAG stockwork. Stockwork quartz has $\delta^{18} \mathrm{O}=7.9 \%$ o-11.7\%o, indicating temperatures of $260^{\circ}-360^{\circ} \mathrm{C}$ in equilibrium with hydrothermal fluid $(1.7 \%$ ). The maximum temperatures calculated for quartz yield temperatures identical to those of the vent fluids $\left(360^{\circ}-365^{\circ} \mathrm{C}\right)$. Scatter to higher quartz $\delta^{18} \mathrm{O}$ values and lower calculated temperatures are the results of precipitation of quartz during cooling of hydrothermal fluids and mixing with seawater in the subsurface, plus local ${ }^{18} \mathrm{O}$ enrichments of fluids via interactions with wallrocks. Generally higher $\delta^{18} \mathrm{O}$ values of quartz from the mound compared to the stockwork $(12.3 \% \circ \pm 2.7 \%$ ovs. $8.9 \%$ $\pm 0.9 \%$ o, respectively) reflect lower temperatures in the mound as the result of cooling of the mound by entrained seawater.

The ${ }^{18} \mathrm{O}$-enriched hydrothermal vent fluids are most likely derived from reactions at high temperatures in a deep-seated reaction zone, but limited ${ }^{18} \mathrm{O}$-enrichment of upwelling hydrothermal fluids could result from reaction with fresh or partly chloritized basalt to paragonite beneath the mound. Initial chloritization of basalt by variable
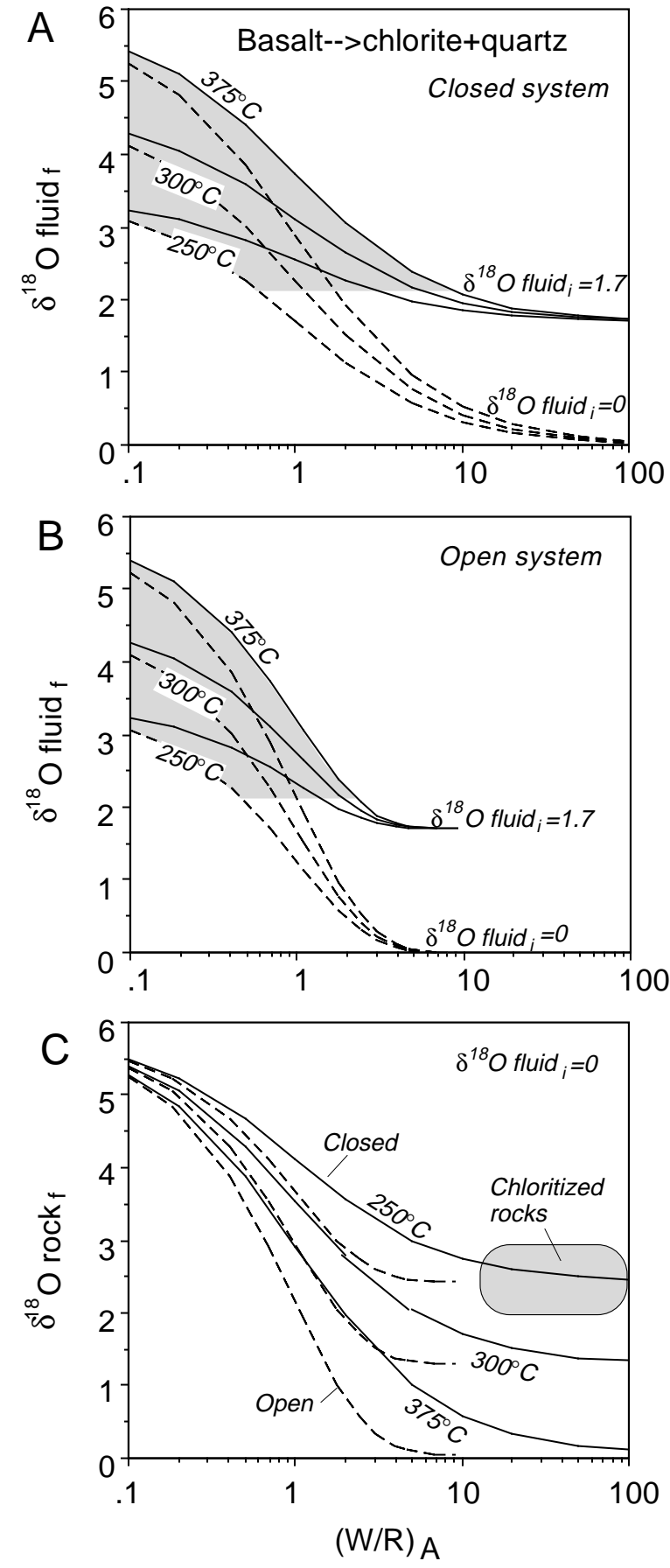

Figure 7. A-C. Oxygen isotopic compositions of fluid and rock for reaction of basalt to chlorite + quartz. Calculations as in Figure 6 , for $\delta_{r}{ }^{i}=5.8 \%$ o, $\delta_{w}{ }^{i}$ $=0 \%$ (seawater) and $1.7 \%$ (hydrothermal fluid). The temperature-dependent mineral-water oxygen isotope fractionations for chlorite and quartz (Wenner and Taylor, 1971; Sharp and Kirschner, 1994) were combined in the proportions in which these minerals occur in the chloritized rocks at the base of TAG-1 ( $85 \%$ chlorite, $15 \%$ quartz). The figures show that this reaction can lead to fluid ${ }^{18} \mathrm{O}$ enrichments only if fluids derived from initial reactions at low water/rock ratio $(<1-5)$ are considered (shaded areas in $\mathrm{A}$ and $\mathrm{B}$ ). The integrated water/rock mass ratios of 30-300 calculated from $\mathrm{Mg}$ uptake agree with calculated $(\mathrm{W} / \mathrm{R})_{\mathrm{A}}$ using the measured $\delta^{18} \mathrm{O}$ of the chloritized rocks $\left(2.1 \% 0^{-3.0 \% o}\right)$ at the temperatures estimated from $\delta^{18} \mathrm{O}$ of chlorites $\left(250^{\circ}-300^{\circ} \mathrm{C}\right)$, as shown by the shaded region in $\mathrm{C}$. 
mixtures of seawater and hydrothermal fluids along the margins of the paragonitic stockwork could also result in ${ }^{18} \mathrm{O}$-enriched fluids.

\section{ACKNOWLEDGMENTS}

The authors gratefully acknowledge J.R. O'Neil for the use of his laboratory, M. Brandriss for invaluable technical assistance, E. Dixon for sample preparation, S. Humphris for additional samples, J. Honnorez for logistical assistance and comments, and R. Knott for numerous discussions. Reviews by Karlis Muehlenbachs and an anonymous reviewer helped clarify some of the interpretations presented here. This work was supported by grants from JOI-USSAC, and was written while JCA was a visiting professor at Université Louis Pasteur, Strasbourg.

\section{REFERENCES}

Alt, J.C., 1995. Subseafloor processes in mid-ocean ridge hydrothermal systems. In Humphris, S.E., Zierenberg, R., Mullineaux, L., and Thomson, R. (Eds.), Seafloor Hydrothermal Systems: Physical, Chemical, Biological and Geological Interactions within Hydrothermal Systems. Geophys. Monogr., Am. Geophys. Union, 91:85-114.

Becker, K., and Von Herzen, R.P., 1996. Pre-drilling observations of conductive heat flow at the TAG active mound using Alvin. In Humphris, S.E., Herzig, P.M., Miller, D.J., et al., Proc. ODP, Init. Repts., 158: College Station, TX (Ocean Drilling Program), 23-29.

Bowers, T.S., and Taylor, H.P., Jr., 1985. An integrated chemical and stableisotope model of the origin of midocean ridge hot spring systems. J. Geophys. Res., 90:12,583-12,606.

Clayton, R.N., and Mayeda, T.K., 1963. The use of bromine pentafluoride in the extraction of oxygen from oxides and silicates for isotopic analysis. Geochim. Cosmochim. Acta, 27:43-52.

Clayton, R.N., O'Neil, J., and Mayeda, T.K., 1972. Oxygen isotope exchange between quartz and water. J. Geophys. Res., 77:3057-3067.

Edmond, J.M., Campbell, A.C., Palmer, M.R., German, C.R., Klinkhammer, G.P., Edmonds, H.N., Elderfield, H., Thompson, G., and Rona, P., 1995. Time-series studies of vent fluids from the TAG and MARK sites (1986, 1990): Mid-Atlantic Ridge: a new solution chemistry model and a mechanism for $\mathrm{Cu} / \mathrm{Zn}$ zonation in massive sulfide ore bodies. In Parson, L.M., Walker, C.L., and Dixon, D.R. (Eds.), Hydrothermal Vents and Processes. Geol. Soc. Spec. Publ. London, 87:77-86.

Edmond J.M., Measures, C., Magnum, B., Grant, B., Sclater, F.R., Collier, R., Hudson, A., Gordon, L.I., and Corliss, J.B., 1979b. On the formation of metal-rich deposits at ridge crests. Earth Planet. Sci. Lett., 46:19-30.

Edmond, J.M., Measures, C., McDuff, R.E., Chan, L.H., Collier, R., and Grant, B., 1979a. Ridge crest hydrothermal activity and the balances of the major and minor elements in the ocean: the Galapagos data. Earth Planet. Sci. Lett., 46:1-18.

Embley, R.W., Jonasson, I.R., Perfit, M.R., Franklin, J.M., Tivey, M.A., Malahoff, A., Smith, M.F., and Francis, T.J.G., 1988. Submersible investigation of an extinct hydrothermal system on the Galapagos Ridge: sulfide mounds, stockwork zone, and differentiated lavas. Can. Mineral., 26:517-539.

Friedman, I., and O'Neil, J.R., 1977. Compilation of stable isotope fractionation factors of geochemical interest. In Fleischer, M. (Ed.), Data of Geochemistry (6th ed.). Geol. Surv. Prof. Pap. U.S., 440-KK:1-12.

Humphris, S.E., Herzig, P.M., Miller, D.J., Alt, J.C., Becker, K., Brown, D., Brügmann, G., Chiba, H., Fouquet, Y., Gemmell, J.B., Guerin, G., Hannington, M.D., Holm, N.G., Honnorez, J.J., Itturino, G.J., Knott, R., Ludwig, R., Nakamura, K., Petersen, S., Reysenbach, A.-L., Rona, P.A., Smith, S., Sturz, A.A., Tivey, M.K., and Zhao, X., 1995. The internal structure of an active sea-floor massive sulphide deposit. Nature, 377:713-716.

Humphris, S.E., Herzig, P.M., Miller, D.J., et al., 1996. Proc. ODP, Init. Repts., 158: College Station, TX (Ocean Drilling Program).

James, R.H., Elderfield, H., Schultz, A., and Dickson, P., 1996. The chemistry of ore-forming diffuse fluids from the TAG hydrothermal site, $26^{\circ} \mathrm{N}$, Mid-atlantic ridge. BRIDGE Newsl., 10:72. (Abstract)
Janecky, D.R., and Shanks, W.C., III, 1988. Computational modeling of chemical and sulfur isotopic reaction processes in seafloor hydrothermal systems: chimneys, massive sulfides, and subjacent alteration zones. Can. Mineral., 26:805-825.

Karson, J.A., and Rona, P.A., 1990. Block tilting, transfer faults, and structural control of magmatic and hydrothermal processes in the TAG area, Mid-Atlantic Ridge $26^{\circ}$ N. Geol. Soc. Am. Bull., 102:1635-1645.

Kleinrock, M.C., Humphris, S.E., and the Deep-TAG Team, 1996. Detailed structure and morphology of the TAG active hydrothermal mound and its geotectonic environment. In Humphris, S.E., Herzig, P.M., Miller, D.J., et al., Proc. ODP, Init. Repts., 158: College Station, TX (Ocean Drilling Program), 15-21.

Lalou, C., Reyss, J.-L., Brichet, E., Rona, P.A., and Thompson, G., 1995. Hydrothermal activity on a $10^{5}$-year scale at a slow-spreading ridge, TAG hydrothermal field, Mid-Atlantic Ridge $26^{\circ}$ N. J. Geophys. Res., 100:17855-17862.

Masuda, H., Chiba, H., Gamo, T., Fujioka K., and Nakamura, M., 1995. Distribution and chemical characteristics of hydrothermal alteration minerals recovered from the TAG active mound, MAR $26^{\circ} \mathrm{N}$. JAMSTEC J. Deep Sea Res., 11:111-124.

Mills, R.A., Alt, J.C., and Clayton, T., 1996. Low temperature fluid flow through sulfidic sediments from TAG: modification of chemical fluxes and alteration of mineral deposits. Geophys. Res. Lett., 23:3495-3498.

Mills, R.A., and Elderfield, H., 1995. Rare earth element geochemistry of hydrothermal deposits from the active TAG mound, $26^{\circ} \mathrm{N}$ Mid-Atlantic Ridge. Geochim. Cosmochim. Acta, 59:3511-3524.

Muehlenbachs, K., and Clayton, R.N., 1972. Oxygen isotope studies of fresh and weathered submarine basalts. Can. J. Earth Sci., 9:172-184.

, 1976. Oxygen isotope composition of the oceanic crust and its bearing on seawater. J. Geophys. Res., 81:4365-4369.

Rona, P.A., Hannington, M.D., Raman, C.V., Thompson, G., Tivey, M.K., Humphris, S.E., Lalou, C., and Petersen, S., 1993. Active and relict seafloor hydrothermal mineralization at the TAG hydrothermal field, MidAtlantic Ridge. Econ. Geol., 88:1987-2013.

Rona, P.A., and Trivett, D.A., 1992. Discrete and diffuse heat transfer at ASHES vent field, Axial Volcano, Juan de Fuca Ridge. Earth Planet. Sci. Lett., 109:57-71.

Saccocia, P.J., and Seyfried, W.E., Jr., 1994. The solubility of chlorite solid solutions in $3.2 \mathrm{wt} \% \mathrm{NaCl}$ fluids from $300-400^{\circ} \mathrm{C}, 500 \mathrm{bars}$. Geochim. Cosmochim. Acta. 58:567-585.

Savin, S.M., and Lee, M., 1988. Isotopic studies of phyllosilicates. In Bailey, S.W. (Ed.), Hydrous Phyllosilicates (Exclusive of Micas). Min. Soc. Am., Rev. Mineral., 19:189-223.

Schultz, A., Delaney, J.R., and McDuff, R.E., 1992. On the partitioning of heat flux between diffuse and point-source seafloor venting. J. Geophys. Res., 97:12299-12314.

Seyfried, W.E., and Ding, K., 1995. Phase equilibria in subseafloor hydrothermal systems: a review of the role of redox, temperature, $\mathrm{pH}$ and dissolved $\mathrm{Cl}$ on the chemistry of hot spring fluids at mid-ocean ridges. In Humphris, S., Lupton, J., Mullineaux, L, and Zierenberg, R. (Eds.), Physical, Chemical, Biological and Geological Interactions Within Submarine Hydrothermal Systems. Am. Geophys. Union, Geophys. Monogr., 91:248-272.

Shanks, W.C., III, Bohlke, J.K., and Seal, R.R., II, 1995. Stable isotopes: tracers of interactions between fluids, minerals, and organisms. In Lupton, J., Mullineaux, L., and Zierenberg, R. (Eds.), Physical, Chemical, Biological and Geological Interactions Within Submarine Hydrothermal Systems. Am. Geophys. Union, Geophys. Monogr., 91:85-114.

Sharp, Z.D., and Kirschner, D.L., 1994. Quartz-calcite oxygen isotope geothermometry: a calibration based on natural isotopic variations. Geochim. Cosmochim. Acta, 58:4491-4502.

Stakes, D.S., and O'Neil, J.R., 1982. Mineralogy and stable isotope geochemistry of hydrothermally altered oceanic rocks. Earth Planet. Sci. Lett., 57:285-304.

Stein, C.A., and Stein, S., 1994. Constraints on hydrothermal heat flux through the oceanic lithosphere from global heat flow. J. Geophys. Res., 99:3081-3095.

Syers, J.K., Chapman, S.L., Jackson, M.L., Rex, R.W., and Clayton, R.N., 1968. Quartz isolation from rocks, sediments, and soils for determination of oxygen isotopes compositions. Geochim. Cosmochim. Acta, 32:10221025 . 
Taylor, H.P., 1977. Water/rock interactions and the origin of $\mathrm{H}_{2} \mathrm{O}$ in granitic batholiths. J. Geol. Soc. London, 133:509-558.

Tivey, M.A., Rona, P.A., and Schouten, H., 1993. Reduced crustal magnetization beneath the active sulfide mound, TAG hydrothermal field, MidAtlantic Ridge $26^{\circ}$ N. Earth Planet. Sci. Lett., 115:101-115.

Tivey, M.K., Humphris, S.E., Thompson, G., Hannington, M.D., and Rona, P.A., 1995. Deducing patterns of fluid flow and mixing within the TAG active hydrothermal mound using mineralogical and geochemical data. $J$. Geophys. Res., 100:12527-12555.

Von Damm, K.L., 1995. Controls on the chemistry and temporal variability of fluids. In Lupton, J., Mullineaux, L., and Zierenberg, R. (Eds.), Physical, Chemical, Biological and Geological Interactions Within Submarine
Hydrothermal Systems. Am. Geophys. Union, Geophys. Monogr., 91:85114.

Wenner, D.B., and Taylor, H.P., Jr., 1971. Temperatures of serpentinization of ultramafic rocks based on ${ }^{16} \mathrm{O} /{ }^{18} \mathrm{O}$ fractionation between coexisting serpentine and magnetite. Contrib. Mineral. Petrol., 32:165-185.

Date of initial receipt: 3 June 1996

Date of acceptance: 2 December 1996

Ms 158SR-222

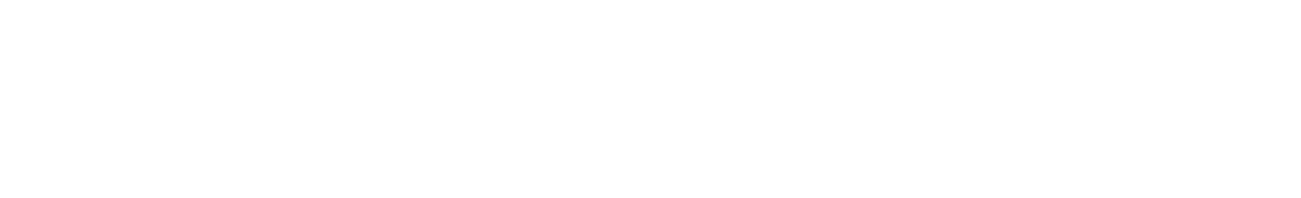

